\title{
Sane and sound: a serologic and molecular survey for selected infectious agents in neozootic Egyptian geese (Alopochen aegyptiacus) in Germany
}

\author{
Hanna Prüter ${ }^{1}$ (D) Gábor Árpád Czirják ${ }^{1} \cdot$ Sönke Twietmeyer ${ }^{2} \cdot$ Timm Harder $^{3} \cdot$ Christian Grund $^{3}$. \\ Kristin Mühldorfer ${ }^{1} \cdot$ Dörte Lüschow ${ }^{4}$
}

Received: 1 March 2018 / Revised: 26 October 2018 / Accepted: 31 October 2018 / Published online: 14 November 2018

(C) Springer-Verlag GmbH Germany, part of Springer Nature 2018

\begin{abstract}
Aquatic birds can act as vectors and reservoir hosts for pathogens relevant for wild birds and poultry as well as human health. In this study, we address the questions (1) if the Egyptian goose (Alopochen aegyptiacus), as one of the most successful neozootic bird species in Europe, carry infectious agents that are relevant for poultry and wild birds and (2) if seasonal prevalences of these infectious agents differ from those of native geese species. In 2015 and 2016, up to 190 Egyptian geese from Western Germany were investigated serologically for antibodies (Ab) against influenza A viruses (IAV), Avian avulavirus 1 (AAvV-1), aviadenoviruses, Duck atadenovirus A (syn.: egg drop syndrome 1976 virus) (EDSV), and West Nile virus (WNV). Ab were detected against IAV in 6.1\% (10/164), against AAvV-1 in $2.4 \%$ (4/165), against EDSV in $15.2 \%$ (16/105), and against aviadenoviruses in $0.86 \%$ (1/116) of the geese blood samples, respectively. None of the birds had Ab against WNV (0/84). PCR-based techniques (cloacal and/or pharyngeal swabs) were applied for the presence of IAV, AAvV-1, Mycoplasma spp., and Riemerella anatipestifer. Riemerella DNA was detected in the pharyngeal swabs with an overall prevalence of $70.3 \%$ (104/148). Neither Mycoplasma DNA nor IAV or AAvV-1 RNA could be detected in the pharynx or cloaca of the examined birds. Our study shows that Egyptian geese are frequent carriers of Riemerella anatipestifer and furthermore provides serological evidence of exposure to IAV, $\mathrm{AAvV}-1$, and EDSV. It is one of very few studies on infectious agents of neozootic bird species. Comparing our results from a neozootic non-migratory goose species with published results from native migratory geese species (bean goose (Anser fabalis) and white-fronted goose (A. albifrons)) and another neozootic non-migratory goose species (Canada goose (Branta canadensis)), we found differences in the seroprevalence of viral pathogens. Native goose species show higher seroprevalences of IAV and AAvV-1, whereas neozootic non-migratory geese reveal higher seroprevalences for EDSV. The findings are discussed in the frame of seasonal variations in selected infectious agents, differences in sampling periods, and contrasting movement ecology of the different geese species.
\end{abstract}

Keywords Alopochen aegyptiacus $\cdot$ Avian avulavirus $\cdot$ Aviadenoviruses $\cdot$ Influenza A virus $\cdot$ Neozootic bird $\cdot$ Riemerella anatipestifer

Electronic supplementary material The online version of this article (https://doi.org/10.1007/s10344-018-1231-9) contains supplementary material, which is available to authorized users.

Hanna Prüter

prueter@izw-berlin.de; prueter@grupr.de

1 Department of Wildlife Diseases, Leibniz Institute for Zoo and Wildlife Research, Alfred-Kowalke-Straße 17,

10315 Berlin, Germany
2 Department of Research and Documentation, Eifel National Park, Urftseestraße 43, Gemünd, D-53937 Schleiden, Germany

3 Friedrich-Loeffler-Institut, Federal Research Institute for Animal Health, Südufer 10, Insel Riems, 17493 Greifswald, Germany

4 Freie Universität Berlin, Institute of Poultry Diseases, Königsweg 63, 14163 Berlin, Germany 


\section{Introduction}

Neozootic species could play a key role in the epidemiology of infectious diseases by carrying pathogens which are alien to native and potentially immunologically naïve animal populations (novel weapon hypothesis) (Callaway and Ridenour 2004; Morand et al. 2015) or by maintaining infection cycles among wild and domestic bird species. Differences in the ecology as well as the use of various habitats can lead to different roles that bird species play in the transmission of infectious diseases. Especially migratory birds harbor numerous infectious microorganisms (Hubálek 2004). Water habitats function as biological hotspots for bird migration (Wahl et al. 2011) and as breeding area of potential invertebrate vectors (e.g., mosquitos). Water birds, including waterfowl (order Anseriformes), have a specific molting biology with a flightless period for approximate 1 month after breeding season. This molting strategy with high agglomeration of individuals in water habitats during that period may potentially favor resident and migratory water birds in their role as reservoirs and carriers of infectious agents of direct and vectorborne transmission.

The Egyptian goose (Alopochen aegyptiacus) is a resident (non-migratory/short distance migratory), monogamous, territorial bird species occurring as neozootic species in a variety of water habitats (e.g., streams, lakes, rivers, ponds) in Europe (Dietzen et al. 2015). In their native range in Africa, these birds are known to be carriers of avian influenza A viruses (IAV) and were reported to transmit low pathogenic subtype H5N5 IAV to ostriches (Pfitzer et al. 2000; Thompson et al. 2008). In South Africa, they are described as excellent sentinels for IAV having the highest total risk score compared to 15 other anatid species (regarding range, abundance, mobility, shared roosts, mixed flocks, foraging, and anthropogenic association) (Cumming et al. 2008; Abolnik et al. 2010). From Egyptian geese in Israel, an avian avulavirus (AAvV) serotype 3b (family Paramyxoviridae, formerly avian paramyxovirus serotype $3 \mathrm{~b}$ ) was isolated and serologically identified. This was the first isolation of AAvV-3b from birds of the Anseriformes group (Shihmanter et al. 1998). Although immature Egyptian geese may cover several thousand square kilometers during juvenile dispersal movements (Böhm, Prüter and Twietmeyer, unpublished data), adult breeding birds are highly resident. These birds most likely do not function as long-distance vectors of infectious agents, but could play a role in the local maintenance of infection cycles.

In Europe, the Egyptian goose is one of the most spreading neozootic bird species (Bauer and Woog 2008). In Germany, the population increased more than 30 -fold over the last 15 years from 250 to 300 breeding pairs in 1999 to at least 8,000 pairs in 2013 (Arnold et al. 2013; Gedeon et al. 2015). Especially the Rhine and Mosel area $\left(50.4^{\circ} \mathrm{N}, 7.6^{\circ} \mathrm{E}\right)$ is a favored habitat in Germany. Compared to its native range, the
Egyptian goose faces fewer predators in novel European habitats (Gyimesi and Lensink 2010). Therefore, its population size can be expected to continuously increase in the next decades, raising the importance of gaining knowledge about the health status of neozootic Egyptian geese and on infectious agents and relevant pathogens, they may carry.

The general knowledge on the presence of infectious agents in neozootic bird species and their potential relevance in transmission cycles is limited. Diseases in neozootic bird populations have been studied mainly in island population of passerines or with focus on one specific pathogen (Blackburn et al. 2009). Like other waterfowl species, Egyptian geese are in close contact to humans and domestic animals and may therefore be important in terms of transmission of infectious agents with public health or economic relevance. Accordingly, the present study was conducted to investigate presence and prevalence of selected infectious agents, which are pathogens in domestic or native wild birds, in a rapidly spreading neozootic bird species by serological tests and molecular detection. Some of these infectious agents like IAV and West Nile virus (WNV) are also important due to their zoonotic potential. The study provides results of importance for future risk analyses and promotes the Egyptian geese as an interesting model species to study pathogen-related hypothesis of animal invasion.

\section{Material and methods}

A total of 190 Egyptian geese were caught in $2015(n=137)$ in spring (April), summer (June and July), and autumn (October and November) and in $2016(n=53)$, in summer (June and July) in the Rhine and Mosel area in Western Germany $\left(50.4^{\circ} \mathrm{N}, 7.6^{\circ} \mathrm{E}\right)$ (Fig. S1) using either loops or landing nets. Each bird was individually banded using engraved rings in addition to unique metal rings (Vogelwarte Radolfzell and Vogelwarte Helgoland). Age, sex, reproductive status, body mass, and wing length were recorded (Table 1).

Table 1 Number of sampled individuals grouped by season, age, and reproductive status

\begin{tabular}{|c|c|c|c|c|}
\hline \multirow[t]{2}{*}{ Year } & \multirow[t]{2}{*}{ Season } & \multicolumn{2}{|l|}{ Adult } & \multirow[t]{2}{*}{ Juvenile } \\
\hline & & Breeding & $\begin{array}{l}\text { Non- } \\
\text { breeding }\end{array}$ & \\
\hline \multirow[t]{3}{*}{2015} & Spring & $7 \lesssim, 49$ & $1 \widehat{\delta}, 0$ 우 & 5 \\
\hline & Summer & $28 \hat{\jmath}, 25 q$ & $4 \hat{\circ}, 1$ 우 & 46 \\
\hline & Autumn & $2 \hat{\jmath}, 2$ 우 & $3 \partial^{\lambda}, 2 q$ & 7 \\
\hline 2016 & Summer & $16 \hat{\jmath}, 13 q$ & $3 \hat{\jmath}, 0$ 우 & 21 \\
\hline Total & & $53 \hat{\jmath}, 44+$ & $11 \hat{\jmath}, 3$ 우 & 79 \\
\hline
\end{tabular}

Season: spring $=$ April, summer $=$ June and July, autumn $=$ October and November 
Reproductive status was defined as breeding (e.g., guiding goslings, showing territorial behavior with a partner, having an egg-laying active cloaca) or non-breeding birds (e.g., not fulfilling criteria of breeding and/or being part of a nonfamily flock).

Blood was drawn either from the vena metatarsalia plantaris superficialis or the vena ulnaris using a needle of 0.06-mm diameter. Blood samples were centrifuged (15 $\mathrm{min}$ ) and sera were frozen in liquid nitrogen within $8 \mathrm{~h}$ after blood draw. Pharyngeal and cloacal swabs were collected from individual birds using sterile cotton swabs and standard procedures in sampling to avoid environmental and cross contamination. Sera and swabs were kept frozen at $-80{ }^{\circ} \mathrm{C}$ until further analysis.

Sample sizes $(n)$ for each assay were dependent on the total amount of serum and swabs available from each individual and therefore differ between the tests that were carried out (Table 2). Sampling was authorized in terms of animal welfare by the Landesuntersuchungsamt Rheinland-Pfalz (G 15-20-005) and Landesamt für Natur, Umwelt und Verbraucherschutz Nordrhein-Westfalen (LANUV) (84-08.04.2015.A266).

\section{Serology}

Influenza A virus A commercial competitive enzyme-linked immunosorbent assay (ELISA) for the detection of antibodies (Ab) against IAV was applied following the manufacture's protocol (IDEXX Montpelier, France, Influenza A Virus Antibody Test Kit). All serum samples being positive in the first run were retested and those being positive twice were defined as truly positive.

Avian avulavirus 1 (formerly avian paramyxovirus 1, syn. Newcastle disease virus) A commercial competitive ELISA for detection of $\mathrm{Ab}$ against $\mathrm{AAvV}-1$ was applied and evaluated according to the manufacture's protocol (ID.vet, Grabels, France, Newcastle Disease Competition, NDVC ver 0913 DE). For positive samples and samples with a percentage of inhibition between 40 and $30 \%$, the ELISA was repeated and only samples being positive twice were considered as positive.

Duck atadenovirus $A$ (syn.: egg drop syndrome 1976 virus) The hemagglutination inhibition (HI) assay using 4 hemagglutinating units of EDSV 127 antigen prepared in chicken embryo liver cells was applied for $\mathrm{Ab}$ detection against EDSV as described (Cha et al. 2013). HI titers of 1:16 and above were interpreted as positive.

Aviadenoviruses The agar gel precipitation test (AGPT) was used for the detection of group-specific antibodies against aviadenoviruses. As antigen, the CELO strain of fowl adenovirus 1 propagated in chicken embryo liver cells was used. The test was performed according to Woernle (1959) using a $1 \%$ agar gel medium.

West Nile virus Serum samples from 2015 were tested applying a commercial competitive ELISA for Ab against Flaviviridae following the manufacture's protocol (ID.vet, West Nile Competition, WNC ver 1014-1P DE).

\section{Molecular analyses}

Influenza A viruses and Avian avulavirus 1 RNA extraction was carried out using the Viral RNA kit of Qiagen (Hilden, Germany) according to the manufacturer's instructions. Realtime reverse transcription PCR (RT-qPCR) was applied for the detection of IAV and AAvV-1 RNA. Generic RT-qPCR specific for the matrix (M) gene of IAV or AAvV-1, respectively, were used as described elsewhere (Wise et al. 2004; Hoffmann

Table 2 Selected antigens and target genes, applied methods, used material, and total sample size $(n)$ per test

\begin{tabular}{|c|c|c|c|c|c|}
\hline \multirow[t]{6}{*}{ Serology } & Antigen & Method & Material & $n$ in 2015 & $n$ in 2016 \\
\hline & IAV & ELISA & Serum & 113 & 51 \\
\hline & $\mathrm{AAvV}-1$ & ELISA & Serum & 114 & 51 \\
\hline & Aviadenoviruses & AGPT & Serum & 116 & 0 \\
\hline & EDSV & $\mathrm{HI}$ & Serum & 58 & 47 \\
\hline & WNV & ELISA & Serum & 84 & 0 \\
\hline \multirow[t]{5}{*}{ Molecular survey } & Target genes & Method & Material & $n$ in 2015 & $n$ in 2016 \\
\hline & IAV matrix gene & RT-qPCR & Cloacal and pharyngeal swab & 126 & 52 \\
\hline & $\mathrm{AAvV}-1$ matrix gene & RT-qPCR & Cloacal and pharyngeal swab & 126 & 52 \\
\hline & R. anatipestifer $16 \mathrm{~S}$ rRNA gene & PCR & Pharyngeal swab & 98 & 50 \\
\hline & Mycoplasma $16 \mathrm{~S}$ rRNA gene & PCR & pharyngeal swab & 98 & 50 \\
\hline
\end{tabular}

$I A V$, influenza A virus; AAvV-1, Avian avulavirus 1; EDSV, Duck atadenovirus A (syn.: egg drop syndrome 1976 virus); WNV, West Nile virus; R., Riemerella; ELISA, enzyme linked immunosorbent assay; $A G P T$, agar gel precipitation test; $H I$, hemagglutination inhibition assay; $P C R$, polymerase chain reaction; $R T-q P C R$, real-time reverse transcription PCR 
et al. 2010). All PCR reactions were performed using the AgPath-ID One-Step RT-PCR kit (Thermofisher, scientific, USA). Thermocycling was performed on a Biorad CFX96 Real-Time cycler (BioRad, Germany). Fluorescent signals were collected during the annealing phase, and the amplification data were analyzed using Bio-Rad CFX Manager 3 software accessing automated fluorescence drift correction for baseline adjustment.

Mycoplasma spp. and Riemerella (R.) anatipestifer DNA was extracted from pharyngeal swabs using the DNeasyTM Tissue kit (Qiagen, Hilden, Germany) following the instructions of the manufacturer. For detection of Mycoplasma DNA, a conventional PCR analysis with primers located within the $16 \mathrm{~S}$ ribosomal RNA (16S rRNA) gene was performed according to Lierz et al. (2007) using illustra PuReTaq Ready-To-Go PCR Beads (GE Healthcare, Munich, Germany). For detection of $R$. anatipestifer specific DNA, a conventional $16 \mathrm{~S}$ rRNA gene-based PCR was used with primers described by Tsai et al. (2005). Amplification was performed using the Taq PCR Master Mix Kit (Hilden, Qiagen), $1 \mu \mathrm{M}$ of each primer and $5 \mu \mathrm{l}$ DNA. PCR was started with a denaturation step at $94{ }^{\circ} \mathrm{C}$ (3 $\mathrm{min}$ ), followed by the thermal cycling (40 cycles: denaturation at $94{ }^{\circ} \mathrm{C}(1 \mathrm{~min})$, annealing $60{ }^{\circ} \mathrm{C}(1 \mathrm{~min})$, extension $72^{\circ} \mathrm{C}(1.5 \mathrm{~min})$, and ended with an elongation step at $72{ }^{\circ} \mathrm{C}(5 \mathrm{~min})$. Analysis of PCR products was carried out by $1.2 \%$ agarose gel electrophoresis and ethidium bromide staining $(2 \mu$ l ethidium bromide $(1 \%) / 100 \mathrm{ml}$ agarose gel). To verify the specificity, selected PCR products of both PCR assays were further investigated by sequence analysis. For this purpose, PCR products were gel purified by the MinElute PCR Purification Kit ${ }^{\circledR}$ according to the manufacturer's instruction (Hilden, Qiagen) and were sequenced one directional by a commercial sequencing service (LGC Genomics $\mathrm{GmbH}$, Berlin, Germany).

\section{Statistical analysis}

The influence of sex, age, and body condition (scaled mass index according to Peig and Green (2009) using wing length as linear body measurement) on the occurrence of $R$. anatipestifer was tested using a generalized linear mixed model with a binomial distribution. The occurrence of $R$. anatipestifer was set as the binominal response variable. Sex, age, body condition, season of sampling, and year functioned as predictors in the model. The $\mathrm{R}$ studio ( $\mathrm{R}$ Core Team 2016) "glmer" function from the packages lme4 (Bates et al. 2015) was used for statistical analyses.

\section{Results}

\section{Serology}

\section{IAV and AAvV-1}

Overall, $6.1 \%(10 / 164)$ of the examined birds were positive for IAV Ab and 2.42\% (4/165) showed Ab against AAvV-1 (Table S1). All ten birds showing Ab against IAV were sampled in summer. Three out of the four positive for AAvV-1 were caught in summer and one in spring. Out of the 10 IAV $\mathrm{Ab}$ positive individuals, four were adult female breeding birds, five adult male breeding birds, and one bird was a juvenile at the age of approximately 8 weeks. This juvenile bird was one out of a flock of eight goslings. We caught two other goslings of the same family which similar to their parents were IAV Ab negative. Two of the positive adults were breeding partners, guiding three goslings in the age of approximately 9 weeks. We sampled one of these three goslings and it was $\mathrm{Ab}$ negative against IAV. One adult female showed Ab against IAV and $\mathrm{AAvV}-1$. Its partner was negative in both ELISAs performed. All four individuals with AAvV-1 Ab were adult breeding birds ( 3 female, 1 male) that were not guiding goslings but showing territorial behavior with a partner. Two partners of the four positive individuals were also sampled but tested negative for $\mathrm{AAvV}-1 \mathrm{Ab}$.

\section{Aviadenoviruses}

One adult female breeding bird out of 116 individuals tested was positive for $\mathrm{Ab}$ against aviadenoviruses, showing a positive reaction already on day one in the AGPT.

\section{EDSV}

The HI test yielded an overall prevalence of $\mathrm{Ab}$ positive geese for EDSV of $15.2 \%$ (16/105) (Table 3). Nine of these birds were from 2015 and seven from 2016. Out of the nine birds from 2015, four were adult female breeding birds, three adult male breeding birds, one was a non-breeding
Table 3 Hemagglutinationinhibition (HI) antibody titers to Duck atadenovirus A (syn.: egg drop syndrome 1976 virus) in sera collected in 2015 and 2016 from Egyptian geese

\begin{tabular}{lllllllll}
\hline Year & $<1: 16$ & $1: 16$ & $1: 32$ & $1: 64$ & $1: 256$ & $1: 1024$ & Ratio* & Prevalence (\%) \\
\hline 2015 & 48 & 5 & 2 & 1 & 0 & 1 & $9 / 58$ & 15.52 \\
2016 & 40 & 1 & 3 & 2 & 1 & 0 & $7 / 47$ & 14.89 \\
\hline
\end{tabular}

*ratio of positive sera to total number tested 
male (with an old healed leg fracture), and one was a juvenile bird that was already fledged ( $>10$ weeks). All Ab positive individuals from 2016 were adult breeding birds (5 females, 2 males). Family members (e.g., partner or goslings) of EDSV Ab positive individuals were found to be negative. Thirteen of the positive individuals were sampled in summer, the other three in spring.

\section{WNV}

None $(0 / 84)$ of the individuals tested for WNV were $\mathrm{Ab}$ positive.

\section{Molecular analyses}

\section{IAV and AAvV-1}

IAV or AAvV-1 RNA could not be detected by generic RTqPCR analyses in the cloacal and pharyngeal swabs from 178 Egyptian geese (126 individuals from 2015, 52 from 2016).

\section{Mycoplasma spp. and R. anatipestifer}

The Mycoplasma PCR showed fragments of the expected size for some of the individuals but sequencing revealed no mycoplasma-specific results. $R$. anatipestifer DNA was detected in 104 individuals with an overall prevalence of $70.3 \%$. A selection of amplified PCR products was confirmed by Sanger sequencing and 16S rRNA gene sequences matched via BLAST to $99 \%$ with the type strain of $R$. anatipestifer DSM 15868 as well as with a broad collection of different $R$. anatipestifer sequences from the GenBank database (www.ncbi.nlm.nih.gov/genbank). One of the newly obtained 16S sequences is available in GenBank under the accession number MH917256.

Statistical analysis revealed a significant difference in the prevalence of $R$. anatipestifer between the years of sampling (2015: $61.2 \%(n=98,60$ positive) and 2016: $88 \%(n=50,44$ positive) $(p=0.01)$. Age $(p=0.23)$, body condition ( $p=$ $0.92)$, sex $(p=0.36)$, reproductive status $(p=0.48)$, and month of sampling ( $p=0.65$ ) showed no statistically significant correlation with the occurrence of $R$. anatipestifer (general linear mixed model, Laplace approximation).

\section{Discussion}

It is well known that the movement ecology of birds plays a key role in the transmission and persistence of viral pathogens, a good example is highly pathogenic IAV (Olsen et al. 2006). Migratory aquatic bird species are known as natural reservoir hosts for low pathogenic IAV (Webster et al. 1992). Except for IAV, however, the knowledge on the epidemiology of avian pathogens in the wild and the role of geese, especially neozootic ones, as carriers or natural reservoirs for viral and bacterial pathogens relevant for animal and human health is limited.

To date, the duration of detectable $\mathrm{Ab}$ responses to infectious agents in wild birds is not well understood and serological reactions can be species specific, limiting the interpretation of results in general, as shown for IAV (Suarez and Schultz-Cherry 2000). Applying competitive, non-speciesspecific ELISAs (IAV and AAvV-1) and standard serological test (EDSV), we found low seroprevalences for these agents. These results, even at low prevalence, indicate that Egyptian geese may be potential vectors for IAV, AAvV-1, and EDSV and that wild bird populations in Western Germany are exposed to these infectious agents.

By comparing our serological results with results from previous studies on other geese species, we found differences in the seroprevalence of IAV, AAvV-1, and EDSV between different species (Table 4). Native European migratory species, e.g., greater white-fronted goose (Anser albifrons), seem to be more exposed to IAV showing mean seroprevalence of $10.6 \%$ (Kruckenberg et al. 2011) compared to neozootic resident species, such as Egyptian and Canadian geese (Branta canadensis) which show $6.1 \%$ and $2.8 \%$ seroprevalences, respectively (this study, Bönner et al. 2003). Similar trends can be observed also in case of AAvV-1 (Table 4). In contrast, neozootic resident species have a higher seroprevalence for EDSV compared to migratory species (Table 4). The trend seems to be consistent when comparing the seroprevalences of these viruses between native and neozootic Canada geese populations. Canada geese, which are migratory in North America, show higher seroprevalences for IAV and AAvV-1 in their native ranges than the neozootic, resident birds in Germany (Bönner et al. 2003; Brown et al. 2010; Kistler et al. 2012). This might reflect the overall prevalence of these viruses in bird population of a specific region. Whereas $\mathrm{AAvV}-1$ is endemic in many African countries, Europe is largely Newcastle disease free, with only sporadic outbreaks especially in eastern countries ("OIE World Animal Health Information System 2017"). However, vaccination with live virus vaccines is widely applied and mandatory for domestic chicken and turkeys in Germany. As AAvV-1 serology does not give information on the pathotype (Dimitrov et al. 2016), it cannot be distinguished whether antibodies were induced by apathogenic genotype class I: lentogenic vaccine type or prevalent pigeon type avian avulavirus 1 viruses.

Seasonal dynamics in the presence of infectious agents and associated transmission cycles are well known for viruses such as IAV as well as AAvV-1. They have been intensively studied in European mallards (Anas platyrhynchos) (LatorreMargalef et al. 2014; Wille et al. 2015) and, for example, a decline in seroprevalences of Ab against IAV in summer was reported by Tolf et al. (2013). In contrast to previous studies 
on wild geese, the IAV Ab positive geese from this study were caught in summer (Table 4). Moreover, three out of four individuals showing $\mathrm{Abs}$ against $\mathrm{AAvV}-1$ were caught in summer. Hence, the reported differences in seroprevalences of the different geese species may be driven by different ecological traits (e.g., movement) as suggested above or could be driven by seasonal differences in sampling of investigated animals. In line with this, $\mathrm{AAvV}-1$ seroprevalence in greater white-fronted goose shows clear seasonal variation (Table 4). Molecular results from a previous study in Germany revealed a prevalence of $13.8 \%$ (4/29) for AAvV-1 in Canada geese during molt in autumn and of 1.6\% (2/128) in white-fronted geese in winter (Kruckenberg et al. 2011). Another RT-PCR-based study by (Fouchier et al. 2003) reported a prevalence of $1.4 \%$ for IAV in wild geese (i.e., white-fronted, greylag (A. anser) and brent goose (Branta bernicla) ratio 20/1387) and of 2.6\% in wild ducks (i.e., widgeon (Anas penelope), mallard (A. platyrhynchos), shoveler (A. clypeata), and teal (A. crecca) ratio 57/2232) on wintering grounds in northern Europe. In contrast, fecal samples from 119 greylag geese captured at the beginning of the breeding season in April 2003 in Norway tested negative by PCR for IAV and AAvV1 (Lillehaug et al. 2005). In the present study, all cloacal and pharyngeal swabs were PCR-negative for IAV and AAvV-1 and collected either in spring, summer, or autumn but not during the winter season. It seems likely that PCR results for
IAV and AAvV-1 may also be biased due to the seasonal variation in prevalence of these viruses. Correlations between IAV shedding and Ab response in Egyptian geese were intensively studied by (Burger et al. 2012). Following their results, we can conclude from our findings that within 28 days before sampling most likely none of the birds were newly infected with IAV, although a comparably low seroprevalence of $6.1 \%$ (10/164) for IAV and of 2.42\% (4/165) for AAvV-1 (Table 4) indicate previous exposure to these viruses.

Aviadenoviruses (former group I adenoviruses) have been isolated from different avian species including geese and ducks (McFerran and Smyth 2000). In the present study, Ab against aviadenoviruses were detected only in one serum sample suggesting a very low seroprevalence. However, the lack of sensitivity of the AGPT especially after primary infection summarized by McFerran and Smyth (2000) may have influenced these results.

EDSV was reported to be a potential agent of acute respiratory syndromes of farm goslings (Ivanics et al. 2001). In free ranging waterfowl populations from South Carolina, an overall EDSV seroprevalence of $42.8 \%$ (65/152, HI titer $\geq 1: 16)$ was reported by Gulka et al. (1984), pointing out that this virus indeed circulates among wild bird. In our study, we found a clearly lower seroprevalence of $15.2 \%$ (16/105, HI titer $\geq$ 1:16). Most seropositive blood samples were collected from adult breeding individuals. Hence, from our data and from the

Table 4 Overview of serological results for influenza A virus (IAV), Avian avulavirus 1 (AAvV-1) and Duck atadenovirus A (syn.: egg drop syndrome 1976 virus) (EDSV) from Egyptian geese compared to published results from other wild geese species

\begin{tabular}{|c|c|c|c|c|c|c|c|c|c|c|c|c|c|c|}
\hline & \multicolumn{7}{|c|}{ Native and Migratory } & \multicolumn{7}{|c|}{ Neozootic and Short-migratory/ Non-migratory } \\
\hline & $\begin{array}{l}\text { Spe- } \\
\text { cies }\end{array}$ & $\begin{array}{l}\text { Preva- } \\
\text { lence (\%) }\end{array}$ & Ratio* & $95 \% \mathrm{CI}$ & $\begin{array}{l}\mathrm{Re}- \\
\text { gion }\end{array}$ & Season & Reference & $\begin{array}{l}\text { Spe- } \\
\text { cies }\end{array}$ & $\begin{array}{l}\text { Prevalence } \\
(\%)\end{array}$ & Ratio* & $95 \% \mathrm{CI}$ & $\begin{array}{l}\mathrm{Re}- \\
\text { gion }\end{array}$ & Season & Reference \\
\hline \multirow{3}{*}{ IAV } & ANAL & 10.6 & $11 / 104$ & $4.7-16.5$ & GE & winter & $\begin{array}{l}\text { Kruckenberg } \\
\text { et al., } 2011\end{array}$ & BRCA & 2.8 & $3 / 107$ & $0.6-8.0$ & GE & spring & $\begin{array}{l}\text { Bönner et al., } \\
2003\end{array}$ \\
\hline & BRCA & 23.6 & $25 / 106$ & $15.9-32.8$ & NA & spring & $\begin{array}{l}\text { Brown et al., } \\
2010\end{array}$ & ALEG & 6.1 & $\begin{array}{l}10 / 16 \\
4\end{array}$ & $\begin{array}{l}2.96- \\
10.93\end{array}$ & GE & $\begin{array}{l}\text { spring, summer, } \\
\text { autumn }\end{array}$ & own data \\
\hline & BRCA & 15 & $483 / 3205$ & $13.8-16.4$ & NA & $\begin{array}{l}\text { sum- } \\
\text { mer }\end{array}$ & $\begin{array}{l}\text { Kistler et al., } \\
2012\end{array}$ & & & & & & & \\
\hline & \multicolumn{7}{|c|}{ Native and Migratory } & \multicolumn{7}{|c|}{ Neozootic and Short-migratory/ Non-migratory } \\
\hline \multirow{4}{*}{$\mathrm{AAvV}-1$} & ANAL & 1.6 & $2 / 128$ & $0.19-5.53$ & GE & winter & $\begin{array}{l}\text { Kruckenberg } \\
\text { et al. } 2011\end{array}$ & BRCA & 13.8 & $4 / 29$ & $\begin{array}{l}3.89- \\
31.66\end{array}$ & GE & winter & $\begin{array}{l}\text { Kruckenberg et } \\
\text { al. } 2011\end{array}$ \\
\hline & ANAL & 40 & $26 / 65$ & $27.9-53.0$ & $\mathrm{GE}$ & autumn & $\begin{array}{l}\text { Hlinak et al., } \\
1998\end{array}$ & BRCA & 8.4 & $9 / 107$ & $3.9-15.4$ & GE & spring & $\begin{array}{l}\text { Bönner et al. } \\
2003\end{array}$ \\
\hline & ANFA & 50 & $32 / 65$ & $36.6-61.9$ & GE & autumn & $\begin{array}{l}\text { Hlinak et al. } \\
1998\end{array}$ & ALEG & 2.42 & $4 / 165$ & $0.66-6.09$ & GE & $\begin{array}{l}\text { spring, summer, } \\
\text { autumn }\end{array}$ & own data \\
\hline & BRCA & 17 & $40 / 236$ & $12.4-22.4$ & NA & & $\begin{array}{l}\text { Bradshaw } \\
\text { and Trainer, } \\
1966\end{array}$ & & & & & & & \\
\hline & \multicolumn{7}{|c|}{ Native and Migratory } & \multicolumn{7}{|c|}{ Neozootic and Short-migratory/ Non-migratory } \\
\hline \multirow{3}{*}{ EDSV } & ANAL & 10.6 & $11 / 104$ & $5.4-18.14$ & GE & winter & $\begin{array}{l}\text { Kruckenberg } \\
\text { et al. } 2011\end{array}$ & BRCA & 18.69 & $\begin{array}{l}20 / 10 \\
7 \\
\end{array}$ & $11.8-27.4$ & GE & spring & $\begin{array}{l}\text { Bönner et al. } \\
2003\end{array}$ \\
\hline & ANAL & 5 & $3 / 65$ & $1.1-12.9$ & GE & autumn & $\begin{array}{l}\text { Hlinak et al. } \\
1998\end{array}$ & ALEG & 15.2 & $\begin{array}{l}16 / 10 \\
5\end{array}$ & $\begin{array}{l}8.97- \\
23.56\end{array}$ & GE & $\begin{array}{l}\text { spring, summer, } \\
\text { autumn }\end{array}$ & own data \\
\hline & ANFA & 8 & $5 / 65$ & $2.5-16.7$ & GE & autumn & $\begin{array}{l}\text { Hlinak et al. } \\
1998\end{array}$ & & & & & & & \\
\hline
\end{tabular}

$I A V$, influenza A virus; $A A v V-1$, Avian avulavirus 1; EDSV, Duck atadenovirus A (syn.: egg drop syndrome 1976 virus)

ANAL, Anser albifrons; BRCA, Branta canadensis; ANFA, Anser fabalis; ALEG, Alopochen aegyptiacus

$G E$, Germany; NA, North America

$C I$, confidence interval

* Ratio of positive to total number of tested

Season: in our own data, all positive individuals were captured in spring or summer (highlighted) 
current literature, it is not apparent at which age EDSV exposure may take place in wild water birds and whether EDSV infections significantly affects the health status of goslings.

Sera collected from Egyptian geese in 2015 were screened serologically for WNV Ab but tested negative. Previous studies have shown $\mathrm{Ab}$ positive birds in Germany, including one waterfowl species (Cygnus olor) (Linke et al. 2007). Additionally, common mosquitos (Culex pipiens and C. torrentium) especially from southern Germany have been found to be highly susceptible to WNV and could function as vectors in virus transmission between wild birds and humans (Leggewie et al. 2016).

Riemerella spp. is known avian pathogens, especially for water and gallinaceous birds (Hubálek 2004) and $R$. anatipestifer plays an important economic role in the health of farm ducks worldwide (Hess et al. 2013). Although $R$. anatipestifer has been isolated from wild birds (including waterfowl) in Germany with clinical and pathological signs (Hinz et al. 1998), studies on its prevalence and ecology in Europe are scarce. High $R$. anatipestifer prevalence in wild birds rates from $80 \%$ in Denmark (Ryll et al. 2001) up to 95\% in South Korea (Cha et al. 2015) and disease-associated serotypes were also found in the pharynges of apparently healthy domestic or wild ducks, respectively. In this study, Egyptian geese showed no clinical signs of riemerellosis but $R$. anatipestifer specific DNA was detected by PCR with a high prevalence in pharyngeal swabs. Conclusions on bacterial fitness or virulence by serotyping were not possible due to the absence of isolates. However, based on results from previous studies, it is very likely that free-ranging waterfowl may carry $R$. anatipestifer as a commensal bacterium in their oropharynges and could possibly be involved in domestic transmission cycles.

Summarizing, this is the first extensive study on selected infectious agents in the Egyptian goose, a neozootic bird species in Europe, that is, native to Africa and could therefore carry infectious agents of different ecological relevance. Overall, our results show that Egyptian geese in Germany are in contact with viruses (i.e., IAV, AAvV-1, and EDSV) and harbor bacteria (i.e., $R$. anatipestifer) known from native waterfowl species in Europe and therefore may be involved in infection cycles of wild and domestic birds. Nevertheless, the viral seroprevalences found in invasive Egyptian geese are low. We highlight differences in seroprevalences for IAV, AAvV-1, and EDSV between geese species with different migratory behavior and assume that migratory behavior could drive the abundance of pathogens in wild geese species. A systematic meta-analysis on different geese species in the context of pathogen transmission cycles could reveal a more comprehensive picture of the ecological background of these findings. Further parameters such as phylogeny, season of sampling, life history traits, and habitat range would need to be considered.
Except for R. anatipestifer, the low prevalence of the investigated infectious agents in Egyptian geese from Germany is likely driven by seasonality but may also support healthrelated hypothesis on animal invasion such as the "enemy release" and "evolution of increased competitive ability" hypotheses or could provide evidence for a highly immune competent species (Callaway and Ridenour 2004; Morand et al. 2015). Comparative studies on African Egyptian geese in their natural range would help to better understand the possible ecological role of invasive species in novel habitats and to follow these two hypotheses. In the frame of the One Health concept, the Egyptian goose can serve as a model to investigate the long-term impact of neozootic species with close contacts to native birds, poultry, and humans.

Acknowledgments This research was undertaken as part of the Graduate School IMPact-Vector funded by the Senate Competition Committee grant (SAW-2014-SGN-3) of the Leibniz Association and financially supported by the Ministry of Rhineland-Palatinate (Ministerium für Umwelt, Energie, Ernährung und Forsten, Project Nr: Gz. 105-63 313/ 2015-40). Hanna Prüter is also an associated doctoral student of the GRK2046 from the German Research Foundation (DFG). Additional support was received from the project AquaVir (Leibniz Association, SAW-2015-IZW-1 440), especially from Alex D. Greenwood, for which we are grateful. We are thankful to Lorena Derezanin, Elke Dyrks, Birgit Göllner, Gabriele Grotehenn, and Michaela Mann for their technical assistance; to Sarah Brüggemann-Schwarze for her help with the ELISA; to Niklas Böhm, Lorena Derezanin, Sophie Ewert, Lea Jäger, Oliver Krone, Manuela Merling de Chapa, Katja Pohle, Felix Prüter, and Jannis Twietmeyer for their assistance during field or laboratory work.

\section{Compliance with ethical standards}

Conflict of interest The authors declare that they have no conflict of interest.

Ethical approval All applicable institutional and/or national guidelines for the care and use of animals were followed.

\section{References}

Abolnik C, Gerdes GH, Sinclair M, Ganzevoort BW, Kitching JP, Burger CE, Romito M, Dreyer M, Swanepoel S, Cumming GS, Olivier AJ (2010) Phylogenetic analysis of influenza A viruses (H6N8, H1N8, H4N2, H9N2, H10N7) isolated from wild birds, ducks and ostriches in South Africa from 2007 to 2009. Avian Dis 54:313-322

Arnold JM, Greiser G, Kampmann S and Martin I (2013) Status und Entwicklung ausgewählter Wildtierarten in Deutschland. Jahresbericht 2013. Wildtier-Informations- system der Länder Deutschlands (WILD). Deutscher Jagdverband; Berlin

Bates D, Mächler M, Bolker B, Walker S (2015) Fitting linear mixedeffects models using lme4. J Stat Softw 67(1):1-48

Bauer H-G, Woog F (2008) Nichtheimische Vogelarten (Neozoen) in Deutschland, Teil I: Auftreten, Bestände und status - non-native and naturalized bird species (neozoa) in Germany, part I: occurrence, population size and status. Vogelwarte 46(2008):157-194

Blackburn TM, Lockwood JL and Cassey P (2009) Avian invasions: the ecology and evolution of exotic birds. Oxford University press, Oxford ; New York 
Bönner BM, Jäger S, Reichel U, Lutz W, Wissing J, Knickmeier W et al (2003) Untersuchungen zum Gesundheitsstatus von Kanadagänsen (Branta canadensis, Linnaeus, 1758) in Nordrhein-Westfalen an Hand der Analyse von Eiern. Z Jagdwiss 49:61-76

Brown JD, Luttrell MP, Berghaus RD, Kistler W, Keeler SP, Howey A, Wilcox B, Hall J, Niles L, Dey A, Knutsen G, Fritz K, Stallknecht DE (2010) Prevalence of antibodies to type A influenza virus in wild avian species using two serological assays. J Wildl Dis 46:896-911

Burger CE, Abolnik C, Fosgate GT (2012) Antibody response and viral shedding profile of Egyptian geese (Alopochen aegyptiacus) infected with low pathogenicity H7N1 and H6N8 avian influenza viruses. Avian Dis 56:341-346

Callaway RM, Ridenour WM (2004) Novel weapons: invasive success and the evolution of increased competitive ability. Front Ecol Environ 2:436-443

Cha S-Y, Kang M, Park C-K, Choi K-S, Jang H-K (2013) Epidemiology of egg drop syndrome virus in ducks from South Korea. Poult Sci 92:1783-1789

Cha S-Y, Seo H-S, Wei B, Kang M, Roh J-H, Yoon R-H, Kim JH, Jang HK (2015) Surveillance and characterization of Riemerella anatipestifer from wild birds in South Korea. J Wildl Dis 51:341-347

Cumming GS, Hockey PAR, Bruinzeel LW, Du Plessis MA (2008) Wild bird movements and avian influenza risk mapping in Southern Africa. Ecol Soc 13(2):26

Dietzen, C., Dolich, T., Grunwald, T., Keller, P. and Kunz, A. (2015) Die Vogelwelt von Rheinland-Pfalz. Band 2 Entenvögel bis Storchenvögel (Anseriformes-Ciconiformes). Gesellschaft für Ornithologie Rheinland-Pfalz Landau

Dimitrov KM, Ramey AM, Qiu X, Bahl J, Afonso CL (2016) Temporal, geographic, and host distribution of avian paramyxovirus 1 (Newcastle disease virus). Infect Genet Evol 39:22-34

Fouchier RAM, Olsen B, Bestebroer TM, Herfst S, van der Kemp L, Rimmelzwaan GF, Osterhaus ADME (2003) Influenza A virus surveillance in wild birds in Northern Europe in 1999 and 2000. Avian Dis $47: 857-860$

Gedeon K, Sudfeldt C, Dougalis P (eds) (2015) Atlas Deutscher Brutvogelarten - Atlas of German Breeding Birds, neue Ausg. Dachverband Deutscher Avifaunisten, Münster, Westf

Gulka CM, Piela TH, Yates VJ, Bagshaw C (1984) Evidence of exposure of waterfowl and other aquatic birds to the haemagglutinating duck adenovirus identical to EDS-76 virus. J Wildl Dis 20:1-5

Gyimesi A, Lensink R (2010) Risk analysis of the Egyptian goose in the Netherlands. Bureau Waardenburg BV Culomborg, The Netherlands

Hess C, Enichlmayr H, Jandreski-Cvetkovic D, Liebhart D, Bilic I, Hess M (2013) Riemerella anatipestifer outbreaks in commercial goose flocks and identification of isolates by MALDI-TOF mass spectrometry. Avian Pathology 42:151-156

Hinz K, Ryll M, Köhler B, Glünder G (1998) Phenotypic characteristics of Riemerella anatipestifer and similar micro-organisms from various hosts. Avian Pathology 27:33-42

Hoffmann B, Harder T, Lange E, Kalthoff D, Reimann I, Grund C et al (2010) New real-time reverse transcriptase polymerase chain reactions facilitate detection and differentiation of novel a/H1N1 influenza virus in porcine and human samples. Berliner und Muenchener Tierarztliche Wochenschrift 123:286-292

Hubálek Z (2004) An annotated checklist of pathogenic microorganisms associated with migratory birds. J Wildl Dis 40:639-659

Ivanics E, Palya V, Glavits R, Dan A, Palfi V, Reeesz T et al (2001) The role of egg drop syndrome virus in acute respiratory disease of goslings. Avian Pathology 30:201-208

Kistler WM, Stallknecht DE, Deliberto TJ, Swafford S, Pedersen K, Why KV, Wolf PC, Hill JA, Bruning DL, Cumbee JC, Mickley RM, Betsill CW, Randall AR, Berghaus RD, Yabsley MJ (2012) Antibodies to avian influenza viruses in Canada geese (Branta canadensis): a potential surveillance tool? J Wildl Dis 48:1097-1101
Kruckenberg H, Müller T, Freuling C, Mühle R-U, Globig A, Schirrmeier H, Buss M, Harder T, Kramer M, Teske K, Polderdijk K, Wallschläger D, Hlinak A (2011) Serological and virological survey and resighting of marked wild geese in Germany. Eur J Wildl Res 57:1025-1032

Latorre-Margalef N, Tolf C, Grosbois V, Avril A, Bengtsson D, Wille M, Osterhaus ADME, Fouchier RAM, Olsen B, Waldenström J (2014) Long-term variation in influenza $A$ virus prevalence and subtype diversity in migratory mallards in northern Europe. Proc R Soc B Biol Sci 281:20140098

Leggewie M, Badusche M, Rudolf M, Jansen S, Börstler J, Krumkamp R, Huber K, Krüger A, Schmidt-Chanasit J, Tannich E, Becker SC (2016) Culex pipiens and Culex torrentiumpopulations from Central Europe are susceptible to West Nile virus infection. One Health 2:88-94

Lierz M, Hagen N, Harcourt-Brown N, Hernandez-Divers SJ, Lüschow D, Hafez HM (2007) Prevalence of mycoplasmas in eggs from birds of prey using culture and a genus-specific mycoplasma polymerase chain reaction. Avian Pathology 36:145-150

Lillehaug A, Monceyron Jonassen C, Bergsjø B, Hofshagen M, Tharaldsen J, Nesse LL et al (2005) Screening of feral pigeon (Colomba livia), mallard (Anas platyrhynchos) and graylag goose (Anser anser) populations for Campylobacter spp., Salmonella spp., avian influenza virus and avian paramyxovirus. Acta Vet Scand 46: 193-202

Linke S, Niedrig M, Kaiser A, Ellerbrok H, Müller K, Müller T et al (2007) Serologic evidence of West Nile Virus infections in wild birds captured in Germany. Am J Trop Med Hyg 77:358-364

McFerran JB, Smyth JA (2000) Avian adenoviruses. Revue Scientifique Et Technique (International Office of Epizootics) 19:589-601

Morand S, Bordes F, Chen H-W, Claude J, Cosson J-F, Galan M et al (2015) Global parasite and Rattus rodent invasions: the consequences for rodent-borne diseases. Integr Zool 10:409-423

OIE World Animal Health Information System. URL http://www.oie.int/ wahis_2/public/wahid.php/Diseaseinformation/ Diseaseoutbreakmaps [accessed 21 June 2017]

Olsen B, Munster VJ, Wallensten A, Waldenstrom J, Osterhaus ADME, Fouchier RAM (2006) Global patterns of influenza A virus in wild birds. Science 312:384-388

Peig J, Green AJ (2009) New perspectives for estimating body condition from mass/length data: the scaled mass index as an alternative method. Oikos 118:1883-1891

Pfitzer S, Verwoerd DJ, Gerdes GH, Labuschagne AE, Erasmus A, Manvell RJ, Grund C (2000) Newcastle disease and avian influenza A virus in wild waterfowl in South Africa. Avian Dis 44:655-660

R Core Team. (2016) R: a language and environment for statistical computing. R Foundation for Statistical Computing, Vienna, Austria

Ryll M, Christensen H, Bisgaard M, Christensen JP, Hinz KH, Köhler B (2001) Studies on the prevalence of Riemerella anatipestifer in the upper respiratory tract of clinically healthy ducklings and characterization of untypable strains. J Vet Med B Infect Dis Vet Public Health 48:537-546

Shihmanter E, Weisman Y, Lublin A, Mechani S, Gruenberg R, Horowith H, Lipkind M (1998) Avian paramyxoviruses serotype 3 isolated from captive birds in Israel: clinical signs, pathology, and antigenic characterization. Avian Dis 42:418-422

Suarez DL, Schultz-Cherry S (2000) Immunology of avian influenza virus: a review. Dev Comp Immunol 24:269-283

Thompson PN, Sinclair M, Ganzevoort B (2008) Risk factors for seropositivity to $\mathrm{H} 5$ avian influenza virus in ostrich farms in the Western Cape Province, South Africa. Prev Vet Med 86:139-152

Tolf C, Latorre-Margalef N, Wille M, Bengtsson D, Gunnarsson G, Grosbois V, Hasselquist D, Olsen B, Elmberg J, Waldenström J (2013) Individual variation in influenza A virus infection histories and long-term immune responses in mallards. PLoS One 8:e61201 
Tsai H-J, Liu Y-T, Tseng C-S, Pan M-J (2005) Genetic variation of the ompA and 16S rRNA genes of Riemerella anatipestifer. Avian Pathology 34:55-64

Wahl J, Dröschmeister R, Langgemach T and Sudfeldt (Hrsg.) C (2011) Vögel in Deutschland - 2011. DDA, BfN, LAG VSW, Münster

Webster RG, Bean WJ, Gorman OT, Chambers TM, Kawaoka Y (1992) Evolution and ecology of influenza A viruses. Microbiol Rev 56: $152-179$

Wille M, Avril A, Tolf C, Schager A, Larsson S, Borg O, Olsen B, Waldenström J (2015) Temporal dynamics, diversity, and interplay in three components of the virodiversity of a mallard population: influenza A virus, avian paramyxovirus and avian coronavirus. Infect Genet Evol 29:129-137

Wise MG, Suarez DL, Seal BS, Pedersen JC, Senne DA, King DJ, Kapczynski DR, Spackman E (2004) Development of a real-time reverse-transcription PCR for detection of Newcastle disease virus RNA in clinical samples. J Clin Microbiol 42:329-338

Woernle H (1959) Diagnose der infektiösen Bronchitis der Hühner mit Hilfe der Präzipitationsreaktion im festen Agarmedium. Monatshefte für Tierheilkunde, Stuttgart 11:154-167 